\title{
1940, DE FRANCISCO PAULO RIBEIRO ROCHA
}

\author{
ROCHA, Francisco Paulo Ribeiro. 1940. Vi- \\ tória da Conquista: Gráfica Laser7, 2018.
}

Sicário, assassino de aluguel e pistoleiro, dentre outros, são nomes dispensados a uma determinada pessoa contratada para, como o próprio nome sugere, cometer um ou mais assassinatos, em troca de dinheiro. Essa é a trama do livro intitulado 1940, de autoria do Dr. Francisco Paulo Ribeiro Rocha, que, além de um renomado médico, é, também, escritor, historiador, romancista, artista plástico e cantor, ainda que nas horas vagas, atributos raros para uma pessoa de formação nas Ciências Médicas.

A sensibilidade literária do Dr. Francisco tem sido evidenciada em seus inúmeros livros de enredo, trama e estilos diferentes, tendo, contudo, como pano de fundo questões relacionadas com a ética, a moral, os bons costumes e tudo que diz respeito aos fatores sociais, políticos, históricos, religiosos, familiares e de cunho amoroso.

\footnotetext{
* Professor Pleno da Universidade Estadual do Sudoeste da Bahia (Uesb). Doutor em Educação pela Southern Illinois University at Carbondale, Estados Unidos.
} 
Embora se trate de um romance aparentemente violento, já que lida com conspiração criminosa, 1940 nos apresenta uma infinidade de ações em que o autor, com muita técnica, sutileza e sabedoria, discorre, em uma linguagem apropriada e convincente, sobre valores familiares, lições de amizade, resignação, confiança, perseverança, simplicidade, bondade e outros atributos da índole humana.

Agripino, protagonista da trama, que tem a incumbência de assassinar o coronel Antonio da Paz, desafeto do coronel Zeca Molego, nos conduz a uma viagem em que o bem e o mal se entrecruzam gerando uma história recheada de surpresas e de resultados nada convencionais, como a pura e inocente amizade do pistoleiro com o vaqueiro Ezaqueu e sua esposa, a tentativa de estabelecimento de romance entre Agripino e Flordinice, mas, sobretudo, o firme propósito do pistoleiro em levar adiante seu ofício de matar, apesar da experiência vivida na Fazenda São Bernardo, lugar de refúgio, ao lado de pessoas honestas, trabalhadeiras, dedicadas, amigas, puras, pacíficas e completamente do bem.

O autor, no decorrer da história, narrada com fascínio, encanto e deslumbramento, mas também com muita coerência e com senso de responsabilidade, nos apresenta, juntamente com a questão criminosa, aspectos positivos de uma sociedade complexa em que os problemas familiares, o analfabetismo e a falta de ensinamentos de valores morais, sociais e éticos podem induzir o indivíduo a trilhar o caminho do mal. Isso fica muito claro na atitude de Agripino. Ele teve toda oportunidade de se redimir, se emendar e sair da vida do crime, mas optou por dar continuidade a um terrível ofício para o qual, segundo ele, havia nascido. Ademais, tinha que seguir os passos e o exemplo do seu pai, que havia sido, também, um pistoleiro de aluguel.

O drama interior de Agripino, depois de sua convivência com Ezaqueu e seus familiares, na Fazenda São Bernardo, é digno de análise e reflexão. Por um momento, ele considerou a possibilidade de largar a vida criminosa e se dedicar ao bem, porém, uma voz interior lhe dizia que se assim o fizesse, estaria indo de encontro a sua própria honra. Para ele, a honra se constituía em continuar naquela vida pregressa, sem se deixar levar por 
momentos de fraqueza. Daí a decisão de Agripino em levar a cabo seu contrato e acabar, de uma vez por todas, com a vida do Coronel Antonio da Paz e a de dois de seus capangas.

Em uma mescla de ficção e realidade, o autor nos leva a uma caminhada turística e de reconhecimento pela cidade que serve como palco da história. Nessa caminhada, passamos por ruas, ruelas, avenidas, praças antigas, becos escuros e sombrios, casarões coloniais, construções centenárias, monumentos, igrejas, hospitais, bares, botecos e prostíbulos, em cujas rodas de conversa se tratava desde amenidades aos mais altos papos de conotação política, histórica e social, a exemplo de um diálogo sobre a Segunda Guerra Mundial, travado por dois homens que se encontravam sentados à mesa no Bar Gato Preto. Esse diálogo se materializa em uma verdadeira aula de História Geral, Política e até mesmo de Geografia, já que menciona os países envolvidos na guerra, a função de cada um e sua implícita localização territorial.

Fugindo um pouco da expectativa de um "final feliz", o conto nos surpreende, no meu entendimento, por dois motivos. Primeiro, pela grande decepção do leitor ao tomar conhecimento de que Flordinice, uma jovem prendada, bonita, de bons costumes e formação, haver sido preterida por Agripino, que preferiu honrar sua sina de pistoleiro de aluguel, a tentar viver um amor que talvez lhe trouxesse paz, felicidade e desse significado a sua vida. Segundo, que não deixa de estar ligado, também, ao primeiro motivo, o fato de Agripino romper todas as barreiras para concretizar uma ação maldosa e por se sentir acima do bem e do mal.

A tarefa é concluída e Agripino fugiu sem deixar rastro, ou pelo menos sem ser capturado, o que simboliza a habilidade e a destreza de um profissional dessa natureza. Contudo, as pegadas de Agripino são encontradas e perseguidas na busca de uma sociedade em que o bem possa sempre vencer o mal, e que a felicidade possa reinar nos corações de pessoas puras, inocentes e bem-intencionadas como Ezaqueu e Madalena.

1940 descreve uma época em que o ofício de matar, profissão que, por sinal, atravessou os séculos, chama a atenção para a fragilidade humana de uma sociedade corrompida, porém real. Trata-se de uma leitura cheia de suspense, de angústia, mas também de 
esperança, em que o leitor entra no texto e se torna personagem de uma história cujas peculiaridades do perfil criminal nos leva a um desfecho inesperado e surpreendente.

Recebido em: 17/08/2018.

Aprovado em: 20/11/2018. 